\title{
Pengendalian Inflasi di Indonesia Berbasis Kebijakan Fiskal dengan Model Seemingly Unrelated Regression
}

\author{
Lia Nazliana Nasution ${ }^{1 *}$, Ade Novalina ${ }^{2}$ \\ ${ }^{1,2}$ Program Studi Ekonomi Pembangunan, Universitas Pembangunan Panca Budi Medan \\ Jl. Jend. Gatot Subroto Km. 4,5 Medan 20122 Indonesia \\ *e-mail : lianazliana@dosen.pancabudi.ac.id
}

\begin{abstract}
ABSTRAK
Artikel Info

Received :

17 Februari 2020

Revised :

07 Maret 2020

Accepted :

13 Juni 2020

Penelitian ini bertujuan untuk melihat seberapa efektif kebijakan fiskal dapat mengendalikan inflasi di Indonesia. Variabel kebijakan fiskal yang digunakan yaitu penerimaan pajak, pengeluaran pemerintah, dan investasi asing langsung (FDI). Data yang digunakan berjenis data sekunder runtun waktu mulai dari tahun 1982 sampai dengan 2018. Berdasarkan hasil penelitian dengan menggunakan metode Seemingly Unrelated Regression (SUR), menunjukkan bahwa variabel kebijakan fiskal yaitu pendapatan pajak, FDI, dan pengeluaran pemerintah berpengaruh signifikan terhadap perkembangan inflasi di Indonesia. Pendapatan pajak berpengaruh signifikan terhadap pengeluaran pemerintah. Begitu juga dengan FDI signifikan mempengaruhi jumlah uang beredar di Indonesia selama periode pengamatan.
\end{abstract}

Kata kunci : Kebijakan Fiskal, Inflasi, Indonesia.

\section{Inflation Control In Indonesia Based On Fiscal Policy With The Seemingly Unrelated Regression Model}

\begin{tabular}{l} 
ABSTRACT \\
\cline { 2 - 2 } This study aims to see how effectively fiscal policy can control \\
inflation in Indonesia. The fiscal policy variables used are tax \\
revenue, government expenditure, and foreign direct investment \\
(FDI). The data used are secondary data types ranging from 1982 \\
to 2018. Based on the results of research using the Seemingly \\
Unrelated Regression (SUR) method, shows that fiscal policy \\
variables measured through tax revenues, FDI, and government \\
spending, have a significant effect on the development of \\
Indonesia's inflation. Tax revenue has a substantial impact on \\
government spending. Likewise, FDI has a significant impact on \\
the money supply in Indonesia during the observation.
\end{tabular}

Keywords : Fiscal Policy, Inflation, Indonesia 
I55N : $1693-7600$ (Print), 155N : 2598-0157 (Online), hutp:/humal.umsu.ac.id//ndex,php/ekawan

\section{PENDAHULUAN}

Indonesia sebagai negara berkembang sering sekali terjadi gejolak dalam menjaga kestabilan kegiatan perekonomiannya. Apabila perekonomian tidak stabil, maka akan timbul masalah-masalah ekonomi seperti salah satunya tingkat inflasi yang tinggi serta menurunnya nilai mata uang rupiah. Pengendalian inflasi merupakan sasaran akhir dari kebijakan moneter yang dilakukan oleh Bank Indonesia. Namun tak hanya kebijakan moneter, kebijakan fiskal pun mampu mengendalikan inflasi. Beberapa penelitian sudah banyak dilakukan untuk melihat dampak kebijakan fiskal bagi pengendalian inflasi, seperti yang dilakukan oleh Surjaningsih, Utari, \& Trisnanto (2012), López-Martín, Aguilar, \& Samano (2018), Otto \& Ukpere (2015), dan lainnya.

Inflasi merupakan suatu masalah ekonomi yang dapat menimbulkan dampak yang sangat luas. Apabila inflasi berada pada angka yang tinggi, akan menyebabkan pertumbuhan ekonomi yang melambat, tingkat pengangguran yang bertambah, dan menurunnya nilai mata uang rupiah. Oleh karena itu inflasi adalah sasaran utama pada kebijakan pemerintahan.

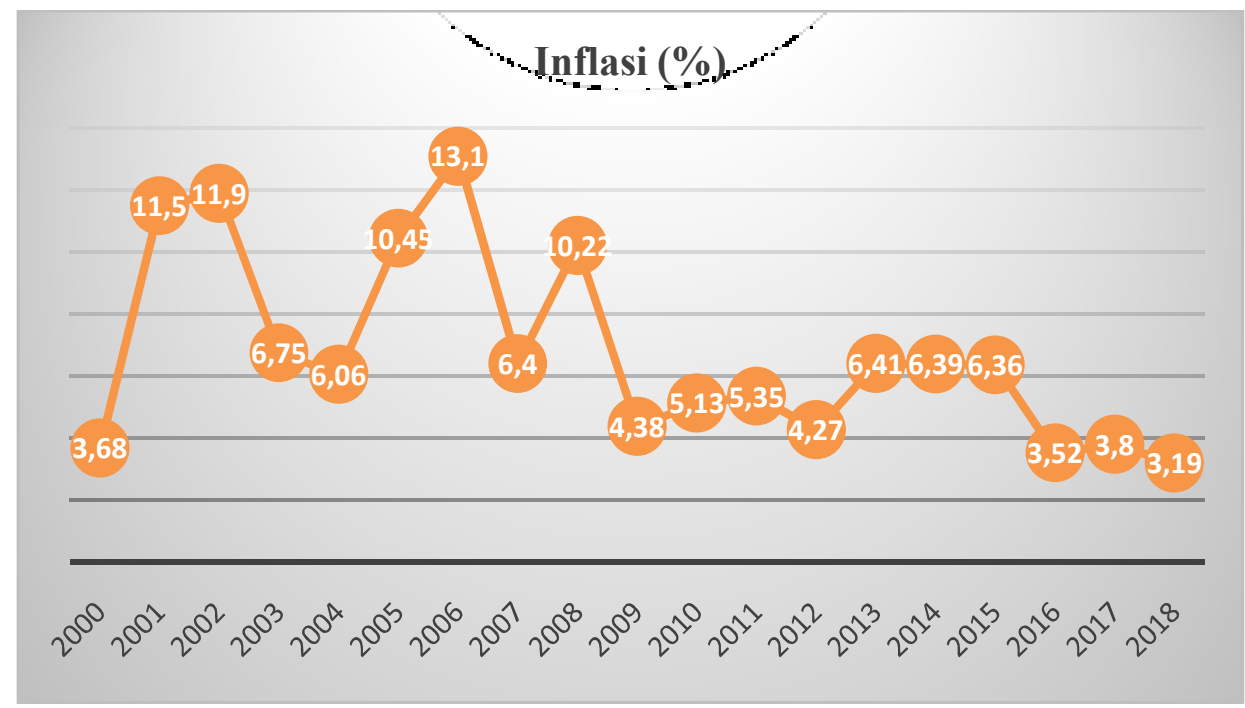

Sumber: World Bank, 2019.

Gambar 1. Inflasi di Indonesia, 2000 - 2018

Gambar 1 di atas menunjukan data pertumbuhan inflasi yang berfluaktif dari tahun 2000 sampai 2018. Tingkat fluktuasi yang tajam terjadi mulai tahun 2000 hingga 2008. Inflasi tertinggi terjadi pada tahun 2006 yaitu sebesar 13,1\%. Hal ini disebabkan keamanan dalam negeri yang kurang kondusif yang dipicu oleh kebijakan pemerintah yang menaikkan harga BBM, tarif listrik, dan telepon (https://www.bps.go.id/). Mulai tahun 2009 sampai dengan 2018 inflasi di Indonesia masih berfluktuasi namun kenaikan maupun penurunannya tidak begitu tajam. Inflasi terendah terjadi di tahun 2018 yaitu sebesar $3,19 \%$.

Dalam penargetan inflasi, kerangka kebijakan moneter dijalankan dengan pendekatan berdasarkan harga besaran moneter. Namun nilai inflasi yang terjadi sering tidak sesuai dengan target yang sudah ditetapkan. Hal ini dipengaruhi oleh kebijakan-kebijakan yang dilakukan, baik dalam bidang moneter ataupun fiskal. Penelitian ini dilakukan khusus untuk melihat seberapa efektif kebijakan fiskal dalam mengendalikan inflasi di Indonesia dengan pendekatan model SUR. 


\section{KAJIAN TEORI \\ Inflasi}

Samuelson dan Nordhaus (2011) mendefinisikan inflasi dalam teori ekonomi sebagai "Inflation occurs when the general level of prices is rising", atau dengan kata lain inflasi terjadi ketika harga-harga barang secara umum terus naik. Manurung dan Rahardja (2004) mengatakan bahwa inflasi terjadi pada suatu perekonomian jika: 1) terjadi kenaikan harga, 2) kenaikan harga bersifat umum, dan 3) berlangsung terus menerus. Ada beberapa indikator yang dapat digunakan untuk mengetahui apakah suatu perekonomian sedang dilanda inflasi atau tidak. Indikator tersebut diantaranya: Indeks Harga Konsumen (IHK), Indeks Harga Perdagangan Besar (IHPB), dan GDP Deflator.

Inflasi juga memberikan pengaruh yang cukup besar terhadap pencapaian beberapa tujuan kebijakan makro, seperti pertumbuhan ekonomi, kesempatan kerja, distribusi pendapatan, dan keseimbangan neraca pembayaran. Hal ini dapat memicu munculnya tingkat inflasi yang sangat serius (Sukirno 2004).

\section{Kebijakan Fiskal}

Kebijakan fiskal merupakan penggunaan pengeluaran pemerintah dan perpajakan dalam mempengaruhi perekonomian. Ketika pemerintah memutuskan pembelian barang dan jasa, pembayaran transfer yang dibagikan, ataupun pemungutan pajak, maka pemerintah terlibat dalam kebijakan fiskal (Weil, 2011). Kebijakan fiskal juga dapat mengubah permintaan agregat. Kemampuan kebijakan fiskal dalam mempengaruhi output dengan mempengaruhi permintaan agregat, membuatnya menjadi alat potensial untuk stabilisasi ekonomi.

Ketika resesi, pemerintah dapat menjalankan kebijakan fiskal ekspansif, sehingga output dapat kembali ke tingkat normal dan membuat pekerja yang menganggur kembali bekerja. Ketika terjadi inflasi, pemerintah dapat menjalankan anggaran surplus sehingga membantu memperlambat ekonomi.

\section{METODE}

Model yang digunakan dalam penelitian ini yaitu Seemingly Unrelated Regression (SUR), dengan materi kuantitatif mempergunakan data sekunder selama kurun waktu 37 tahun yakni mulai tahun 1982 sampai dengan 2018. Arnold Zellner memperkenalkan model Seemingly Unrelated Regression (SUR) pertama kali pada tahun 1962. Zellner menyatakan bahwa SUR merupakan model regresi multivariat (multiple regression), dan merupakan bagian dari regresi linier berganda. Model SUR terdiri atas beberapa sistem persamaan yang tidak berhubungan (unrelated) artinya bahwa setiap variabel (dependen maupun independen) terdapat dalam satu sistem.

Persamaan Model SUR:

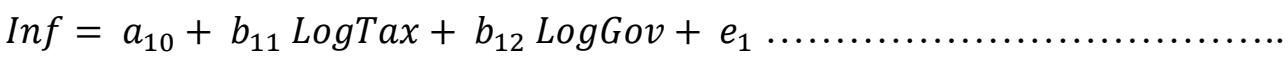

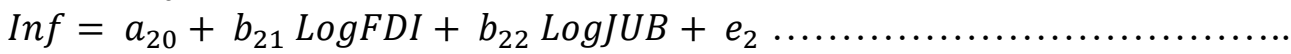

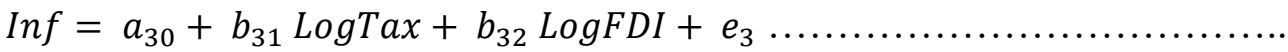

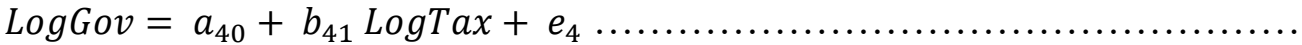

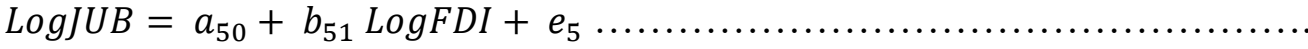

$$
\begin{aligned}
& \text { Keterangan : } \\
& \text { Inf }=\text { Inflasi }(\%) \\
& \text { Tax = Pendapatan pajak } \\
& \text { Gov }=\text { Pengeluaran konsumsi akhir pemerintah } \\
& \text { FDI = Investasi Asing Langsung }
\end{aligned}
$$




\section{EKONOMIKAWAN : Jurnal Ilmu Ekonomi dan Studi Pembangunan}

I55N : $1693-7600$ (print), 155N : 2598-0157 (Online), hutp://rumal.umstiac.id//ndex,php/ekawan

$$
\begin{array}{ll}
\mathrm{JUB} & =\text { Jumlah uang beredar } \\
\mathrm{a} & =\text { konstanta } \\
\mathrm{b} & =\text { koefisien } \\
\mathrm{e} & =\text { error term }
\end{array}
$$

\section{HASIL DAN PEMBAHASAN}

Memelihara kestabilan perekonomian dan pertumbuhan ekonomi merupakan tujuan bagi setiap negara termasuk Indonesia sebagai negara sedang berkembang. Kestabilan ekonomi tersebut menyangkut kestabilan tingkat harga, pendapatan nasional, dan pertumbuhan kesempatan kerja (Watulingas et al., 2016). Salah satu kebijakan yang dilakukan pemerintah untuk menstabilkan ekonomi adalah melalui kebijakan fiskal.

Berikut perkembangan laju pertumbuhan pajak, investasi asing langsung, pengeluaran pemerintah, dan jumlah uang beredar di Indonesia periode tahun 1983 sampai dengan 2018.

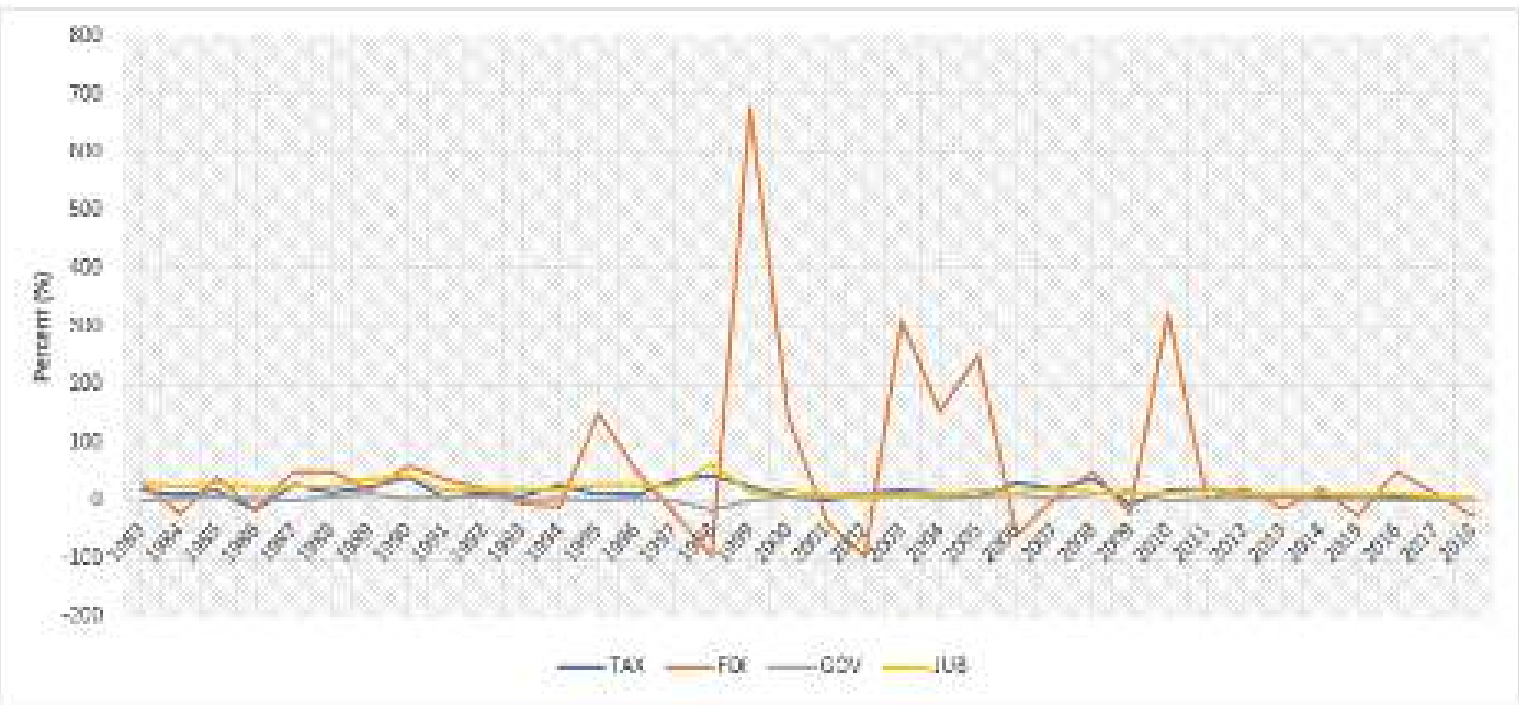

Sumber: World Bank

Gambar 2. Laju Pertumbuhan Variabel, Tahun 1983 - 2018 (\%)

Berdasarkan Gambar 2 di atas, selama 36 tahun yakni mulai tahun 1983 hingga 2018, terlihat perkembangan laju FDI berfluktuasi cukup tajam. Laju pertumbuhan FDI tertinggi yaitu pada tahun 1999 mencapai hingga $700 \%$, sedangkan laju pertumbuhan terendah yaitu pada tahun 1998 mencapai hingga $-100 \%$. Laju pertumbuhan pajak, pengeluaran pemerintah, dan jumlah uang beredar bergerak cukup stabil selama 36 tahun. Laju pertumbuhan pajak tertinggi yaitu pada tahun 1990 sebesar $40 \%$ dan terendah pada tahun 1986 yaitu sebesar $-15 \%$. Laju pertumbuhan pengeluaran pemerintah tertinggi yaitu pada tahun 2009 yaitu sebesar 15\% dan terendah pada tahun 1998 yaitu sebesar $-15 \%$. Laju pertumbuhan jumlah uang beredar tertinggi terjadi tahun 1998 sebesar $62 \%$ dan terendah terjadi tahun 2002 yaitu sebesar 4\%.

Untuk mengetahui estimasi dengan model SUR, maka hasil pengolahan dengan menggunakan Eviews adalah sebagai berikut: 
Published, Volume 20 No. 1, Juli 2020

EKONOMIKAWAN : Jurnal IImu Ekonomi dan Studi Pembangunan

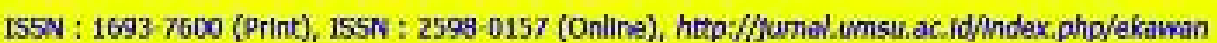

Tabel 1. Hasil Estimasi SUR

\begin{tabular}{|l|c|c|c|c|}
\hline \multicolumn{5}{|l|}{ Estimation Method: Seemingly Unrelated Regression } \\
\hline \multicolumn{5}{|l|}{ Sample: 1982-2018 } \\
\hline & Coefficient & Std. Error & t-Statistic & Prob. \\
\hline C(1) & 726.1576 & 77.71881 & 9.343396 & 0.0000 \\
\hline C(2) & 6.464256 & 0.994419 & 6.500535 & 0.0000 \\
\hline C(3) & -27.66206 & 3.074142 & -8.998303 & 0.0000 \\
\hline C(4) & 38.89372 & 13.21035 & 2.944186 & 0.0037 \\
\hline C(5) & -3.037734 & 0.537377 & -5.652896 & 0.0000 \\
\hline C(6) & 1.050919 & 0.294655 & 3.566603 & 0.0005 \\
\hline C(7) & 41.44808 & 14.08406 & 2.942907 & 0.0037 \\
\hline C(8) & 0.627772 & 0.368588 & 1.70318 & 0.0903 \\
\hline C(9) & -2.460419 & 0.53488 & -4.599943 & 0.0000 \\
\hline C(10) & 23.41059 & 0.414093 & 56.53461 & 0.0000 \\
\hline C(11) & 0.310485 & 0.012663 & 24.51993 & 0.0000 \\
\hline C(12) & 10.65134 & 2.560495 & 4.159873 & 0.0001 \\
\hline C(13) & 1.075776 & 0.119117 & 9.03128 & 0.0000 \\
\hline
\end{tabular}

Sumber: Seemingly Unrelated Regression; Eviews v.10, 2019.

\begin{tabular}{|l|c|}
\hline \multicolumn{1}{|c|}{ Equation: } & R-squared \\
\hline$I N F=C(1)+C(2) * L O G T A X+C(3) * L O G G O V$ & 0.277795 \\
\hline$I N F=C(4)+C(5) * L O G F D I+C(6) * L O G J U B$ & 0.212129 \\
\hline$I N F=C(7)+C(8) * L O G T A X+C(9) * L O G F D I$ & 0.170127 \\
\hline$L O G G O V=C(10)+C(11) * L O G T A X$ & 0.910375 \\
\hline$L O G J U B=C(12)+C(13) * L O G F D I$ & 0.635032 \\
\hline
\end{tabular}

Sumber: Seemingly Unrelated Regression; Eviews v.10, 2019.

\section{Persamaan 1 (Inflasi)}

Berdasarkan hasil estimasi SUR pada Tabel 1 di atas, maka persamaan pertama yang terbentuk adalah :

$$
\text { Inf }=726.1576+6.464256 \operatorname{LogTax}-27.66206 \log G o v+e_{1}
$$

Dari persamaan 6 menunjukkan bahwa pendapatan pajak mempengaruhi inflasi positif dan signifikan dengan koefisien sebesar 6.464256 dan probabilitas sebesar $0.0000<\alpha$ 


\section{EKONOMIKAWAN : Jurnal Ilmu Ekonomi dan Studi Pembangunan}

I55N : $1693-7600$ (Print), 155N : 2598-0157 (Online), hutp://Jumal.umstiac.id/index.php/ekawan

$=0.05$. Ini berarti apabila pendapatan pajak meningkat sebesar $1 \%$ akan meningkatkan inflasi sebesar $6.464256 \%$.

Lain halnya dengan pengeluaran pemerintah mempengaruhi inflasi negatif dan signifikan dengan koefisien sebesar -27.66206 dan probabilitas sebesar $0.0000<\alpha=$ 0.05. Ini berarti apabila pengeluaran pemerintah naik sebesar $1 \%$ akan menurunkan inflasi sebesar $27.66206 \%$.

Nilai koefisien determinasi persamaan 6 seperti yang tertera pada Tabel 1, sebesar 0.277795 yang artinya bahwa secara bersama-sama pendapatan pajak dan pengeluaran pemerintah mampu menjelaskan inflasi sebesar $27.78 \%$ dan sisanya $72.22 \%$ dijelaskan oleh variabel lain yang tidak disertakan di dalam model estimasi.

\section{Persamaan 2 (Inflasi)}

Berdasarkan hasil estimasi SUR pada Tabel 1 di atas, maka persamaan kedua yang terbentuk adalah :

$$
\operatorname{Inf}=38.89372-3.037734 \operatorname{LogFDI}+1.050919 \log J U B+e_{2} \ldots \ldots \ldots
$$

Dari persamaan 7 menunjukkan bahwa investasi asing langsung mempengaruhi inflasi di Indonesia secara negatif namun signifikan dengan koefisien sebesar 3.037734 dan probabilitas sebesar $0.0000<\alpha=0.05$. Ini berarti apabila investasi asing langsung meningkat sebesar 1\% akan menurunkan inflasi sebesar 3.037734\%.

Jumlah uang beredar mempengaruhi inflasi di Indonesia secara positif dan signifikan dengan koefisien sebesar 1.050919 dan probabilitas sebesar $0.0005<\alpha=$ 0.05. Ini berarti apabila jumlah uang beredar naik sebesar $1 \%$ akan menaikkan inflasi sebesar $1.050919 \%$.

Nilai koefisien determinasi persamaan 7 seperti yang tertera pada Tabel 1, sebesar 0.212129 yang artinya bahwa secara bersama-sama FDI dan jumlah uang beredar mampu menjelaskan inflasi sebesar $21.21 \%$ dan sisanya $78.79 \%$ dijelaskan oleh variabel lain di luar model estimasi.

\section{Persamaan 3 (Inflasi)}

Berdasarkan hasil estimasi SUR pada Tabel 1 di atas, maka persamaan ketiga yang terbentuk adalah :

$$
\text { Inf }=41.44808+0.627772 \log T a x-2.460419 \log F D I+e_{3} \ldots \ldots . .(8)
$$

Dari persamaan 8 menunjukkan bahwa pendapatan pajak berpengaruh positif tidak signifikan terhadap inflasi di Indonesia dengan koefisien sebesar 0.627772 dan probabilitas sebesar $0.0903>\alpha=0.05$.

Sedangkan variabel investasi asing langsung mempengaruhi inflasi di Indonesia negatif dan signifikan dengan koefisien sebesar -2.460419 dan probabilitas sebesar $0.0000<\alpha=0.05$. Ini berarti apabila investasi asing langsung naik sebesar $1 \%$ akan menurunkan inflasi sebesar $2.460419 \%$.

Nilai koefisien determinasi persamaan 8 seperti yang tertera pada Tabel 1, sebesar 0.170127 yang artinya bahwa secara bersama-sama pendapatan pajak dan FDI mampu menjelaskan inflasi sebesar $17.01 \%$ dan variabel lain di luar model menjelaskan sisanya $82.99 \%$.

\section{Persamaan 4 (Pengeluaran Pemerintah)}

Berdasarkan hasil estimasi SUR pada Tabel 1 di atas, maka persamaan keempat yang terbentuk adalah :

$$
\text { LogGov }=23.41059+0.310485 \operatorname{LogTax}+e_{4}
$$




\section{EKONOMIKAWAN : Jurnal Ilmu Ekonomi dan Studi Pembangunan}

I55N : $1693-7600$ (print), 155N : 2598-0157 (Online), hutp://rumal.umstiac.id//ndex,php/ekawan

Dari persamaan 9 menunjukkan bahwa pendapatan pajak mempengaruhi pengeluaran pemerintah di Indonesia secara positif signifikan dengan koefisien sebesar 0.310485 dan probabilitas sebesar $0.0000<\alpha=0.05$. Ini berarti apabila pendapatan pajak naik sebesar $1 \%$ akan meningkatkan pengeluaran pemerintah sebesar $0.310485 \%$.

Nilai koefisien determinasi persamaan 9 seperti yang tertera pada Tabel 1, sebesar 0.910375 yang artinya bahwa pendapatan pajak mampu menjelaskan pengeluaran pemerintah sebesar $91.04 \%$ dan sisanya $8.96 \%$ dijelaskan oleh variabel lain di luar model estimasi.

\section{Persamaan 5 (Jumlah Uang Beredar)}

Berdasarkan hasil estimasi SUR pada Tabel 1 di atas, maka persamaan kelima yang terbentuk adalah :

$\log J U B=10.65134+1.075776 \log F D I+e_{5}$

Dari persamaan 10 menunjukkan bahwa investasi asing langsung mempengaruhi jumlah uang beredar positif dan signifikan dengan koefisien sebesar 1.075776 dan probabilitas sebesar $0.0000<\alpha=0.05$. Ini berarti apabila FDI naik sebesar $1 \%$ akan meningkatkan jumlah uang beredar sebesar $0.310485 \%$.

Nilai koefisien determinasi persamaan 10 seperti yang tertera pada Tabel 1, sebesar 0.635032 yang artinya bahwa FDI mampu menjelaskan jumlah uang beredar sebesar $63.50 \%$ dan sisanya $36.5 \%$ dijelaskan oleh variabel lain di luar model estimasi.

\section{SIMPULAN}

Kesimpulan dari penelitian ini bahwa pendapatan pajak, FDI, dan pengeluaran pemerintah berpengaruh signifikan terhadap inflasi di Indonesia selama 37 tahun periode pengamatan yakni mulai tahun 1982 sampai dengan 2018. Ini artinya variabel-variabel kebijakan fiskal cukup efektif dalam mengendalikan inflasi di Indonesia. Jumlah uang beredar juga berpengaruh secara positif dan signifkan terhadap inflasi. Sesuai teori, apabila jumlah uang beredar di masyarakat meningkat, akan memicu terjadinya inflasi.

Pendapatan pajak berpengaruh positif dan signifikan terhadap pengeluaran pemerintah. Ini artinya ketika pendapatan pajak meningkat akan meningkatkan pengeluaran pemerintah. Karena pajak merupakan sumber pendapatan pemerintah terbesar di Indonesia, sehingga pengeluaran pemerintah untuk pembangunan dan lainnya juga dapat meningkat. FDI berpengaruh positif dan signifikan terhadap JUB. Ketika aliran kas masuk bertambah, maka jumlah uang beredar juga meningkat, yang akhirnya dapat memicu terjadinya inflasi.

\section{DAFTAR PUSTAKA}

https://data.worldbank.org/country/indonesia

https://www.bps.go.id/

López-Martín, B., Aguilar, A. R., \& Samano, D. (2018). Fiscal Policy and Inflation: Understanding the Role of Expectations in Mexico. IDB Working Paper Series, IDBWP-893, August 2018.

Manurung, M. \& Rahardja, P. (2004). Uang, Perbankan, dan Ekonomi Moneter (Kajian Kontekstual Indonesia). Jakarta : Lembaga Penerbit FEUI.

Otto, G. \& Ukpere, W., I. (2015). The Impact of Fiscal Policy On Inflation in Nigeria. Risk governance \& control: financial markets \& institutions, 5(1), 123 - 132. 
Samuelson, A., P. \& Nordhaus, D., W. (2011). Makro Ekonomi. Edisi keempat belas, Jakarta: Erlangga.

Sukirno, S. (2004). Makro Ekonomi Teori Pengantar. Jakarta : PT. Raja Grafindo Perkasa.

Surjaningsih, N., Utari, G. A. D., \& Trisnanto, B. (2012). Dampak Kebijakan Fiskal Terhadap Output dan Inflasi. Buletin Ekonomi Moneter dan Perbankan, 14(4), 389 419.

Weil, N., D. (2011). Fiscal Policy. Econlib, Featured Encyclopedia Entry. https://www.econlib.org/library/Enc/FiscalPolicy.html

Watulingas, J., Rotinsulu, O., T., \& Siwu, Dj., F., H. (2016). Pengaruh Aspek Moneter dan Fiskal Terhadap Inflasi di Indonesia. Jurnal Berkala Ilmiah Efisiensi, 16(01), 718 727. 